\title{
The effects of feeding rations that differ in neutral detergent fiber and starch concentration within a day on rumen digesta nutrient concentration, $\mathrm{pH}$, and fermentation products in dairy cows
}

\author{
Y. Ying, L. W. Rottman, ${ }^{1}$ C. Crawford, P. A. Bartell, and K. J. Harvatine ${ }^{2}$ \\ Department of Animal Science, Penn State University, University Park 16802
}

\begin{abstract}
There is a daily pattern of feed intake in the dairy cow, and feeding a single total mixed ration results in variation in the amount of fermentable substrate entering the rumen over the day. The object of this study was to determine if feeding multiple rations over the day that complement the pattern of feed intake would stabilize rumen pool sizes and fermentation. Nine ruminally cannulated cows were used in a $3 \times$ 3 Latin square design with 23 -d periods. Diets were a control diet [33.3\% neutral detergent fiber (NDF)], a low-fiber diet (LF; $29.6 \% \mathrm{NDF}$ ), and a high-fiber diet (HF; $34.8 \%$ NDF). The LF and HF diets were balanced to provide the same nutrient composition as the control diet when cows were fed 3 parts of LF and 7 parts of HF. Cows on the control treatment $(\mathrm{CON})$ were fed at $0900 \mathrm{~h}$, cows on the high/low treatment $(\mathrm{H} / \mathrm{L})$ were fed $\mathrm{HF}$ at $70 \%$ of daily offering at $0900 \mathrm{~h}$ and $\mathrm{LF}$ at $30 \%$ of daily offering at $2200 \mathrm{~h}$, and cows on the low/high $(\mathrm{L} / \mathrm{H})$ treatment were fed $\mathrm{LF}$ at $30 \%$ of daily offering at $0900 \mathrm{~h}$ and $\mathrm{HF}$ at $70 \%$ of daily offering at $1300 \mathrm{~h}$. All treatments were fed at $110 \%$ of daily intake. Preplanned contrasts compared CON with $\mathrm{H} / \mathrm{L}$ and $\mathrm{H} / \mathrm{L}$ with $\mathrm{L} / \mathrm{H}$. Feeding the LF diet in the evening resulted in a large increase in the amount of feed consumed immediately after feed delivery at that feeding. Rumen digesta starch concentration increased and NDF concentration decreased following feeding of the LF diet in both the $\mathrm{L} / \mathrm{H}$ and $\mathrm{H} / \mathrm{L}$ treatments. Starch pool size also increased following feeding of the LF diet in the evening and tended to increase after feeding the LF diet in the morning. Rumen ammonia concentration was increased following feeding of the $\mathrm{HF}$ diet in the morning and the $\mathrm{LF}$ diet in the evening in the $\mathrm{H} / \mathrm{L}$ treatment. Additionally, cis-9 C18:1 and cis-9,cis-12 18:2 are higher in concentrate feeds and were increased after feeding the
\end{abstract}

Received September 18, 2014

Accepted March 2, 2015.

${ }^{1}$ Currrent address: Novozymes Biologicals Inc., Salem, VA 24153.

${ }^{2}$ Corresponding author: kjh182@psu.edu
LF diet in both treatments. Trans fatty acid isomers of the normal and alternate biohydrogenation pathways followed a daily pattern, and the $\mathrm{H} / \mathrm{L}$ treatment increased isomers of the alternate pathway during the overnight period following the evening feeding of the LF diet. Additionally, C17:0 decreased during the overnight period in the H/L treatment. Feeding multiple rations over the day changed feeding behavior, and the combined effect of diet composition and feeding pattern resulted in a change in rumen nutrient pool sizes and fermentation products. Feeding the low-fiber diet in the evening resulted in a large increase in feed intake after feed delivery and did not increase starch intake during the overnight period. The $\mathrm{H} / \mathrm{L}$ treatment failed to stabilize rumen fermentation because of the shift in the feeding pattern. Feeding strategies that feed multiple diets over the day must integrate diet composition and feeding behavior to achieve the desired effect on rumen nutrient pools and fermentation.

Key words: circadian, diurnal, feed intake, rumen fermentation

\section{INTRODUCTION}

Total mixed ration feeding was developed to provide a consistent concentration of fermentable substrate in each meal over the day, and it has become the standard practice for feeding dairy cattle in North America. The common perception is that TMR is a complete substrate that is continually added at a frequency sufficient to allow the rumen to approximate a steady-state fermenter and creates constant fermentation and maximal microbial growth (Coppock et al., 1981). However, ruminal fermentation of cows fed TMR is not constant because of the variation in feed intake across the day, which results in a higher entry rate of fermentable substrate into rumen during the high-intake period of the day. This can be compounded by ration sorting that can occur in some diets where particle size or DM content is such that cows can separate concentrate from forage components of the TMR (Leonardi et al., 2005). Ef- 
forts have been made to stabilize the rate of feed intake by offering feed more often or pushing feed closer to the feeding rail, but an effective frequency of delivering feed 4 or more times per day is not practical on most commercial dairies and simply pushing feed closer to the feeding rail does not significantly increase feeding (DeVries et al., 2005).

Diet fermentability is dependent on the extent and rate of $\mathrm{OM}$ digestibility. Feedstuffs high in sugars, starch, and potentially digestible NDF increase the concentration of fermentable OM, and modification of plant genetics or feed processing can also increase the rate of fermentation (reviewed by Allen, 1997). Highly fermentable feeds result in a rapid production of VFA that reduce ruminal $\mathrm{pH}$ when the rate of production exceeds buffering capacity and absorption. In addition, more-fermentable diets containing less forage reduce rumination and salivary buffer secretion. The resulting low ruminal $\mathrm{pH}$ decreases fiber digestibility and microbial growth and can cause milk fat depression, bloat, laminitis, displaced abomasums, and metabolic acidosis (Owens et al., 1998; Krause and Oetzel, 2006). Importantly, VFA concentration, rumination, and rumen $\mathrm{pH}$ have a wide variation over the day and exhibit a daily rhythm that is highly correlated with the rate of feed intake (Dado and Allen, 1994).

We propose that the daily pattern of feed intake commonly observed in TMR-fed dairy cows creates a large variation in the amount of fermentable carbohydrate entering the rumen over the day that may be stabilized by feeding different diets within a day. Our hypothesis was that feeding a higher fiber diet during the high-intake period of the day, from morning feeding through early evening, and a lower fiber diet during the low-intake period of the day, overnight, would stabilize rumen $\mathrm{pH}$, digesta nutrient composition and pool size, and VFA concentration. A companion paper (Rottman et al., 2015) focuses on the effects on feeding behavior, milk production, milk FA profile, and plasma glucose, insulin, and NEFA concentrations.

\section{MATERIALS AND METHODS}

\section{Animals and Experimental Design}

Nine multiparous Holstein cows (158 \pm 48 DIM, mean $\pm \mathrm{SD}$ ) from the Pennsylvania State University Dairy Herd were randomly assigned to 1 of 3 treatments in a $3 \times 3$ Latin square design with 23 -d periods, as described in the companion paper (Rottman et al., 2015). Cows were housed in tiestalls, and lights were manually controlled with a dark phase from approximately 0000 to $0500 \mathrm{~h}$. Cows were milked in a milking parlor at
0700 and $1700 \mathrm{~h}$. The 3 diets used were a control diet (33.1\% NDF), a low-fiber diet (LF; $29.6 \%$ NDF), and a high-fiber diet (HF; 34.8\% NDF; Table 1). Forage was substituted for ground corn to change diet NDF, whereas other ingredients remained constant. The LF and HF diets were balanced to provide the same nutrient composition as the control diet when combined at a ratio of 3 parts of LF and 7 parts of $\mathrm{HF}$ on a DM basis. Cows on the control treatment $(\mathbf{C O N})$ were fed the control TMR at $0900 \mathrm{~h}$; cows on the high/low treatment $(\mathbf{H} / \mathbf{L})$ were fed HF at $70 \%$ of daily offering at $0900 \mathrm{~h}$ and LF at $30 \%$ of daily offering at $2200 \mathrm{~h}$; and cows on the low/high $(\mathbf{L} / \mathbf{H})$ treatment were fed $\mathrm{LF}$ at $30 \%$ of daily offering at $0900 \mathrm{~h}$ and $\mathrm{HF}$ at $70 \%$ of daily offering at $1300 \mathrm{~h}$ (Figure 1). Diets were analyzed as described in Rottman et al. (2015). The first morning feeding was scheduled to occur following the morning milking. The timing of the second feeding in the $\mathrm{H} / \mathrm{L}$ and $\mathrm{L} / \mathrm{H}$ treatments was based on the predicted time required to consume the amount of feed delivered based on cows fed a TMR ration $1 \times / d$ with minor adjustments in the first days of the experiment based on the time require to consume most of the diet offered first. All cows were fed at $110 \%$ of expected daily intake. Refused feed was removed before delivery of new feed at each feeding. Animal care and procedures were approved by the Pennsylvania State University Institutional Animal Care and Use Committee (\#31694).

\section{Feeding Behavior Observation}

Cows were housed in an automated feed intake observation system as described in the companion paper (Rottman et al., 2015), and amounts of DM, starch, and NDF consumed over 2-h intervals across the day were calculated.

\section{Rumen Sampling and Analysis}

Rumen samples were collected every $9 \mathrm{~h}$ on d 15 to 17 to represent every $3 \mathrm{~h}$ of the day. Samples were taken from 5 different locations in the rumen and composited. Rumen fluid was separated using a nylon screen (1$\mathrm{mm}$ pore size). Whole digesta and fluid were stored at $-20^{\circ} \mathrm{C}$ until further analysis. Immediately upon thawing, the rumen fluid was acidified and analyzed for VFA by gas chromatography (Yang and Varga, 1989). Rumen ammonia was determined according to Broderick and Kang (1980).

Rumen contents were completely evacuated through the rumen cannula at $1500 \mathrm{~h}$ on d $20,0100 \mathrm{~h}$ on d 22 , and $0700 \mathrm{~h}$ on d 23 of each period $(33.5$ and $30.5 \mathrm{~h}$ between evacuations) and weight and volume determined. 
Table 1. Ingredient and nutrient composition of experimental diets

\begin{tabular}{|c|c|c|c|}
\hline \multirow[b]{2}{*}{ Item } & \multicolumn{3}{|c|}{ Diet $^{1}$} \\
\hline & $\mathrm{CON}$ & $\mathrm{HF}$ & LF \\
\hline \multicolumn{4}{|l|}{ Dietary ingredient, $\%$ of DM } \\
\hline Corn silage $^{2}$ & 38.8 & 41.7 & 32.1 \\
\hline Ground corn & 19.3 & 15.1 & 29.1 \\
\hline Alfalfa haylage $^{3}$ & 12.6 & 13.5 & 10.4 \\
\hline Canola meal & 9.6 & 9.6 & 9.6 \\
\hline Cracked roasted soybeans & 7.2 & 7.2 & 7.2 \\
\hline Grass hay and straw ${ }^{4}$ & 4.1 & 4.5 & 3.4 \\
\hline Cookie meal & 3.3 & 3.3 & 3.3 \\
\hline Vitamin and mineral mix ${ }^{5}$ & 3.2 & 3.2 & 3.2 \\
\hline Cottonseed hulls & 1.41 & 1.51 & 1.16 \\
\hline $\mathrm{NPN}^{6}$ & 0.42 & 0.42 & 0.42 \\
\hline \multicolumn{4}{|l|}{ Nutrient composition, \% of DM } \\
\hline $\mathrm{OM}$ & 93.8 & 93.3 & 93.7 \\
\hline NDF & 33.3 & 34.8 & 29.6 \\
\hline Starch & 28.6 & 27.2 & 31.9 \\
\hline $\mathrm{CP}$ & 15.9 & 16.0 & 15.7 \\
\hline \multicolumn{4}{|l|}{ Fatty acids } \\
\hline Total & 3.9 & 3.8 & 4.1 \\
\hline C16:0 & 0.56 & 0.58 & 0.55 \\
\hline $\mathrm{C} 18: 2 \mathrm{n}-6$ & 1.74 & 1.69 & 1.87 \\
\hline C18:1n-9 & 0.92 & 0.90 & 0.97 \\
\hline C18:3n-3 & 0.26 & 0.25 & 0.26 \\
\hline
\end{tabular}

${ }^{1} \mathrm{CON}=$ control, $\mathrm{HF}=$ high-fiber diet, $\mathrm{LF}=$ low-fiber diet.

${ }^{2}$ Contained $39.6 \%$ NDF, $37.0 \%$ starch, and $7.0 \% \mathrm{CP}$ on a DM basis.

${ }^{3}$ Contained $51.1 \%$ NDF and $21.0 \% \mathrm{CP}$ on a DM basis.

${ }^{4}$ Mixed grass hay and wheat straw mixture. Contained $74.7 \%$ NDF and $6.4 \% \mathrm{CP}$ on a DM basis.

${ }^{5}$ Vitamin and mineral mix contained $11 \%$ CP, $18 \%$ NDF, $5.1 \%$ fat, $14 \% \mathrm{Ca}, 0.35 \% \mathrm{P}, 4.6 \% \mathrm{Mg}, 0.42 \% \mathrm{~K}, 0.3 \% \mathrm{~S}, 1,071 \mathrm{mg} / \mathrm{kg} \mathrm{Mn}, 357$ $\mathrm{mg} / \mathrm{kg} \mathrm{Cu}, 1,085 \mathrm{mg} / \mathrm{kg} \mathrm{Zn}, 6.66 \mathrm{mg} / \mathrm{kg} \mathrm{Se}, 6.4 \%$ salt (DM basis), $262,101 \mathrm{IU} / \mathrm{kg}$ of vitamin A, 65,421 IU/kg vitamin D, and 1,972 IU/ $\mathrm{kg}$ vitamin $\mathrm{E}$ (DM basis).

${ }^{6}$ Optigen (Alltech Inc. Nicholasville, KY; 256\% CP, DM basis).

The volume of digesta was determined using barrels calibrated with water in 5-L increments (based on distance to the top of the barrel). Digesta were leveled and lightly compressed using a plywood board cut to fit inside the barrel, and the distance to the top of the barrel was measured and converted to volume based on the calibration curve. A subsample of digesta was separated into solid and liquid fractions and stored at $-20^{\circ} \mathrm{C}$, lyophilized, and composited based on the ratio of solids to liquids on a DM basis. Digesta samples were ground through a 1-mm screen using a Wiley mill (Arthur H. Thomas Co., Philadelphia, PA) and analyzed for DM, starch, NDF, and FA concentration and profile according to Rico et al. (2014).

\section{Rumen pH Observation and Analysis}

Five indwelling $\mathrm{pH}$ data loggers (model 2xKB5; Kahne Animal Health, Auckland, New Zealand) were rotated between animals from d 15 to 20 to allow observation of approximately $3 \mathrm{~d}$ per cow per period.

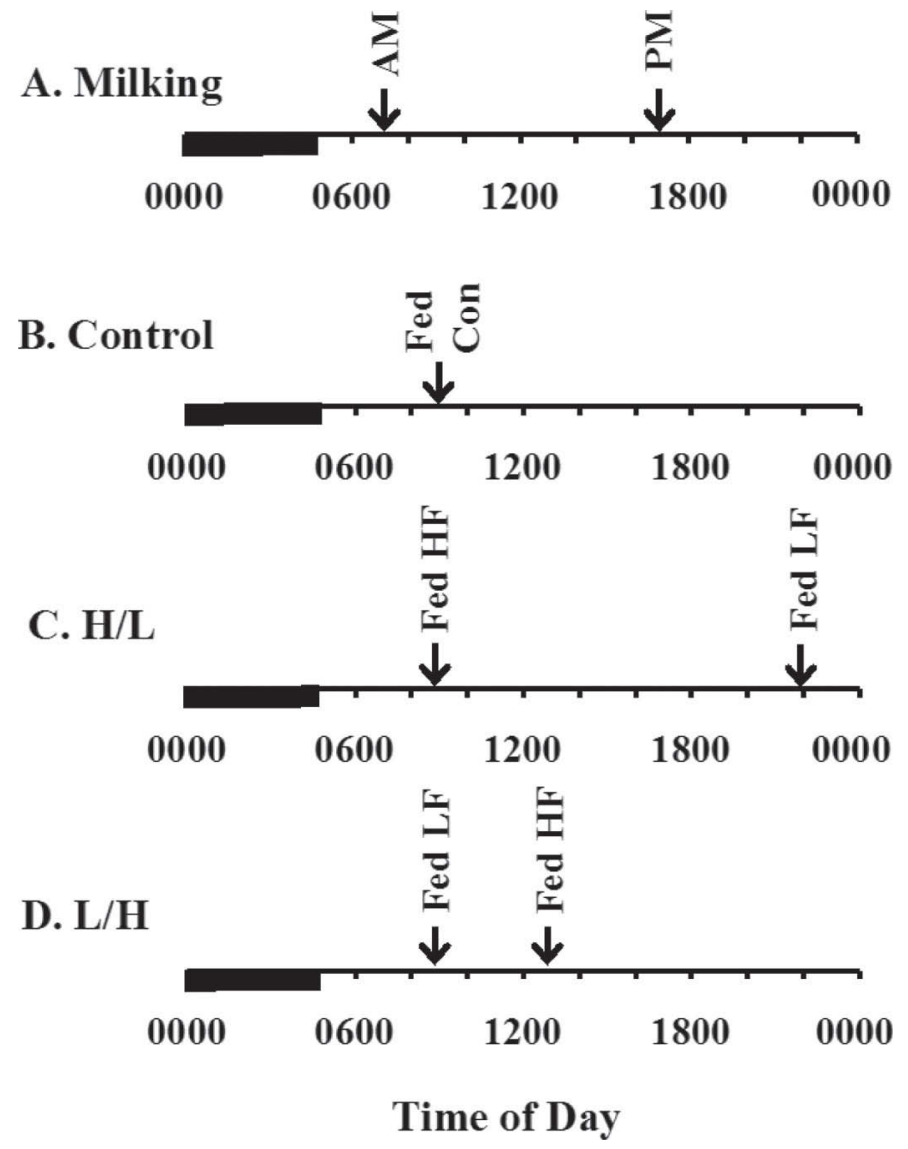

Figure 1. Timing of feeding and milking of 3 treatments tested. All cows were milked at 0700 and $1700 \mathrm{~h}$ each day. Control cows were fed a TMR once per day at $0900 \mathrm{~h}, \mathrm{H} / \mathrm{L}$ were fed a high-fiber (HF) diet at $70 \%$ of daily offering at $0900 \mathrm{~h}$ and a low-fiber (LF) diet at $30 \%$ of daily offering at $2200 \mathrm{~h}$, and $\mathrm{L} / \mathrm{H}$ were fed a low-fiber diet at $30 \%$ of daily offering at $0900 \mathrm{~h}$ and a high-fiber diet at $70 \%$ of daily offering at $1300 \mathrm{~h}$. Dark phase is shown by the black bar.

Ruminal $\mathrm{pH}$ was recorded every $5 \mathrm{~min}$ and a 2-point calibration ( $\mathrm{pH} 4.0$ and 7.0 at $39^{\circ} \mathrm{C}$ ) was conducted before insertion into and after removal from the rumen each day. Data were disregarded if either point was outside \pm 0.1 units from calibration at the time of removal. Mean $\mathrm{pH}$, standard deviation, and time under $\mathrm{pH} 5.8$ and 5.6 were determined for each observation day using Igor Pro 6.2.2.2 (WaveMetrics Inc., Lake Oswego, OR) as described by Oba and Allen (2000). Average rumen $\mathrm{pH}$ every $2 \mathrm{~h}$ across the day was also calculated.

\section{Statistical Analysis}

Daily rumen $\mathrm{pH}$ variables were analyzed by the Fit Model function of JMP (v9.0 and v10.0; SAS Institute Inc., Cary, NC). The model included the random effects of cow, period, and treatment sequence and the fixed effect of treatment. A reduced model was used when 
appropriate based on model adjusted $\mathrm{R}^{2}$. Preplanned contrasts were CON versus $\mathrm{H} / \mathrm{L}$ and $\mathrm{H} / \mathrm{L}$ versus $\mathrm{L} / \mathrm{H}$. Timecourse response variables were analyzed using the MIXED procedure of SAS with repeated measures (SAS Institute Inc.). Fixed effects were treatment, time, and the interaction of treatment and time. Random effects were cow(sequence), sequence, and period, repeated variable was time, and subject was cow $\times$ period. A reduced model was used when appropriate based on Bayesian information criterion. Preplanned contrasts were $C O N$ versus $H / L$ and $H / L$ versus $L / H$ at each time point, and the Kenward-Rogers adjustment for the denominator degrees of freedom was used. Significance and tendencies were declared for main effects at $P<$ 0.05 and $P<0.10$, respectively, and for interactions at $P<0.10$ and $P<0.15$, respectively.

\section{RESULTS AND DISCUSSION}

The goal of the feeding strategies investigated was to provide a more fermentable diet either during the active feeding period after morning feed delivery or during the low feeding period overnight. Feeding the LF diet at the morning feeding was designed to increase fermentable OM intake during the high-intake period of the day and was expected to exacerbate the effect of feeding on rumen parameters. The selection of diets, timing of feeding, and effects on feeding behavior are extensively discussed in the companion paper (Rottman et al., 2015). Briefly, substituting forage for corn grain provided a simple method to change diet fermentability while holding other ingredients constant. Some selection between diets occurred, but the daily average diet consumed in all treatments was very similar in NDF and starch (within 0.2 percentage units; Rottman et al., 2015). The treatments differed in both diet composition and timing of feeding, because the goal was to compare the applied feeding strategies. Feeding times were based on the time required to consume the first diet offered each day based on previous experiments, with slight modification during the initial days of the experiment.

\section{Nutrient Entry into the Rumen}

Dairy cows fed a TMR once per day have a daily pattern of feed intake, with more intake occurring after morning feeding and during the afternoon and early evening and less intake occurring overnight (DeVries et al., 2003; Tolkamp et al., 2011). However, delivery of fresh feed is also a strong stimulus for feeding, with clear increases in intake after feed delivery when cows are fed up to $4 \times / \mathrm{d}$ (DeVries et al., 2005). The goal of the $\mathrm{H} / \mathrm{L}$ treatment was to provide a more consistent
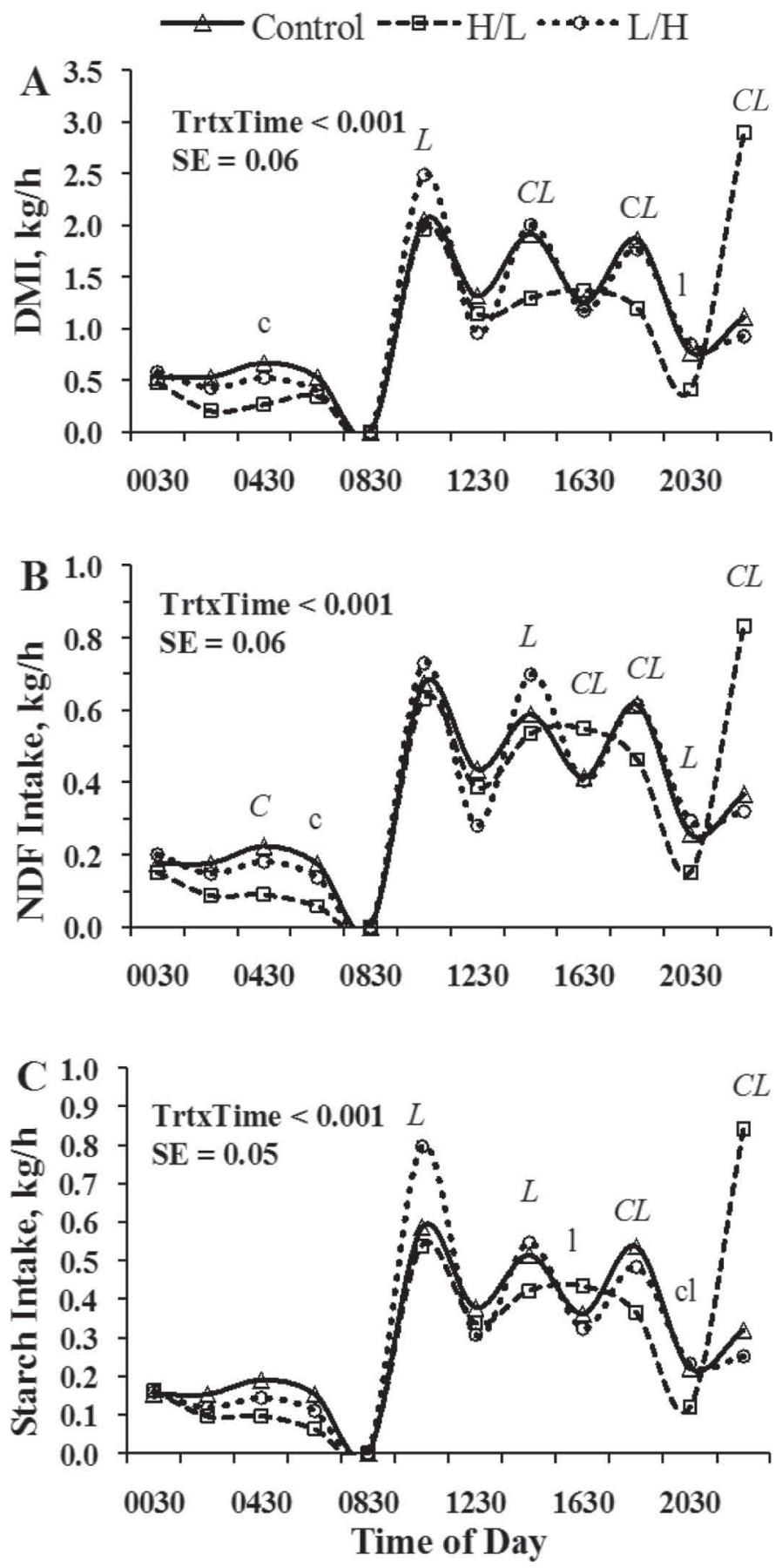

Figure 2. The effect of a single TMR or feeding 2 rations that differ in their fiber and starch concentration at different times of the day on (A) DM, (B) NDF, and (C) starch intake over the day (expressed as $\mathrm{kg} / \mathrm{h}$ ). Control cows were fed a TMR once per day at $0900 \mathrm{~h}, \mathrm{H} / \mathrm{L}$ were fed a high-fiber diet at $70 \%$ of daily offering at $0900 \mathrm{~h}$ and a low-fiber diet at $30 \%$ of daily offering at $2200 \mathrm{~h}$, and $\mathrm{L} / \mathrm{H}$ were fed a low-fiber diet at $30 \%$ of daily offering at $0900 \mathrm{~h}$ and a high-fiber diet at $70 \%$ of daily offering at $1300 \mathrm{~h}$. Preplanned contrasts at each time point are shown (control vs. $\mathrm{H} / \mathrm{L}: C=P<0.05$ and $\mathrm{c}=P<0.1 ; \mathrm{H} / \mathrm{L}$ vs. $\mathrm{L} / \mathrm{H}: L=P<0.05$ and $\mathrm{l}=P<0.1)$. Treatment by time interaction (Trt $\times$ Time) and SE shown within each panel. Dark phase was approximately 0000 to $0500 \mathrm{~h}$. 
Table 2. The effect of feeding a single TMR or feeding 2 rations that differed in their fiber and starch concentration at different times of the day on rumen $\mathrm{pH}$

\begin{tabular}{|c|c|c|c|c|c|c|c|}
\hline Item & \multicolumn{3}{|c|}{ Treatment $^{1}$} & SEM & \multicolumn{3}{|c|}{$P$-value ${ }^{2}$} \\
\hline \multicolumn{8}{|l|}{$\mathrm{pH}$} \\
\hline Mean & 6.0 & 6.0 & 6.0 & 0.06 & 0.87 & 0.61 & 0.78 \\
\hline Minimum & 5.3 & 5.1 & 5.2 & 0.08 & 0.30 & 0.17 & 0.20 \\
\hline Maximum & 6.8 & 6.9 & 6.8 & 0.11 & 0.89 & 0.80 & 0.64 \\
\hline Range & 1.58 & 1.72 & 1.57 & 0.14 & 0.21 & 0.15 & 0.11 \\
\hline 5.6 & 2.8 & 3.8 & 3.3 & 1.02 & 0.61 & 0.33 & 0.65 \\
\hline
\end{tabular}

${ }^{1}$ Least squares means. Control $(\mathrm{CON})$ cows were fed a TMR once per day at $0900 \mathrm{~h} ; \mathrm{H} / \mathrm{L}$ were fed a high-fiber ration at $70 \%$ of daily offering at $0900 \mathrm{~h}$ and a low-fiber ration at $30 \%$ of daily offering at $2200 \mathrm{~h}$; and $\mathrm{L} / \mathrm{H}$ were fed a low-fiber ration at $30 \%$ of daily offering at $0900 \mathrm{~h}$ and a high-fiber diet at $70 \%$ of daily offering at $1300 \mathrm{~h}$.

${ }^{2}$ Main effect of treatment (Trt) and preplanned contrasts (H/L vs. CON and H/L vs. L/H).

intake of starch across the day to reduce the variation in the entry rate of starch into the rumen over the day. However, in the $\mathrm{H} / \mathrm{L}$ treatment, feeding the $\mathrm{HF}$ diet in the morning decreased intake from 1330 to $1530 \mathrm{~h}$ and from $1730 \mathrm{~h}$ until the evening feeding, whereas feeding the LF diet in the evening increased DMI by over 1.9 $\mathrm{kg} / \mathrm{h}$ and starch intake by $2.3 \mathrm{~kg} / \mathrm{h}$ during the $2 \mathrm{~h}$ after feeding compared with CON (Figure 2). Dry matter intake tended to be lower in $\mathrm{H} / \mathrm{L}$ treatment in the early morning (0330 to $0530 \mathrm{~h}$ ) and NDF intake was lower

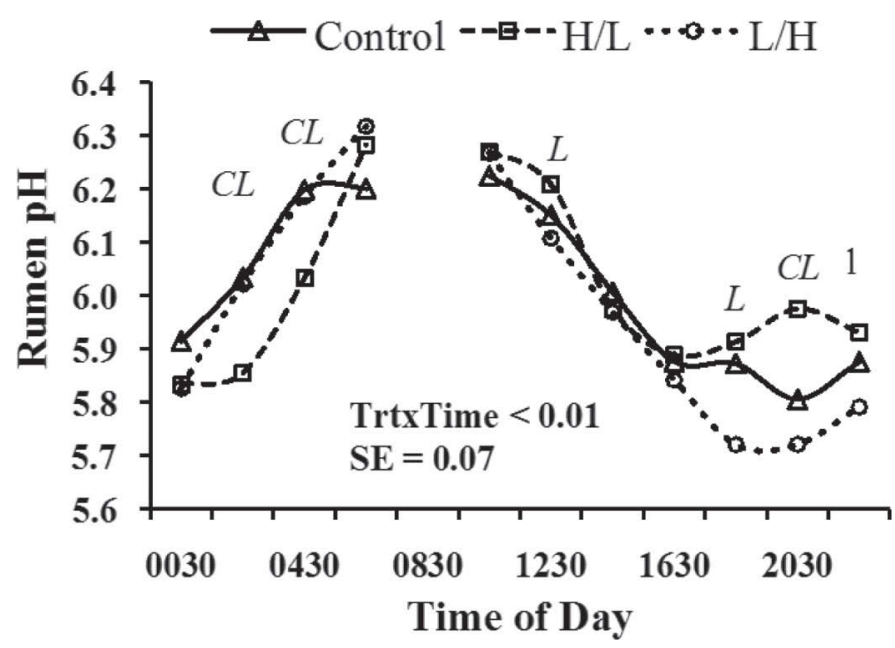

Figure 3. The effect of a single TMR or feeding 2 rations that differ in their fiber and starch concentration at different times of the day on rumen $\mathrm{pH}$ averaged over 2 -h intervals. Control cows were fed a TMR once per day at $0900 \mathrm{~h}, \mathrm{H} / \mathrm{L}$ were fed a high-fiber diet at $70 \%$ of daily offering at $0900 \mathrm{~h}$ and a low-fiber diet at $30 \%$ of daily offering at $2200 \mathrm{~h}$, and $\mathrm{L} / \mathrm{H}$ were fed a low-fiber diet at $30 \%$ of daily offering at $0900 \mathrm{~h}$ and a high-fiber diet at $70 \%$ of daily offering at $1300 \mathrm{~h}$. Probes were removed daily for calibration (0730 to $0900 \mathrm{~h}$ ). Preplanned contrasts at each time point are shown (control vs. H/L: $C=P<0.05$ and $\mathrm{c}=P<0.1 ; \mathrm{H} / \mathrm{L}$ vs. $\mathrm{L} / \mathrm{H}: L=P<0.05$ and $\mathrm{l}=$ $P<0.1$ ). Treatment (Trt) by time interaction and standard error are shown. Dark phase was approximately 0000 to $0500 \mathrm{~h}$. from 0330 to $0530 \mathrm{~h}$ and tended to be lower from 0530 to $0730 \mathrm{~h}$ compared with $\mathrm{CON}$. In the $\mathrm{L} / \mathrm{H}$ treatment, DM and starch intakes were also higher after feeding the $\mathrm{LF}$ diet compared with the $\mathrm{H} / \mathrm{L}$ treatment but followed a similar pattern as the CON group thereafter.

\section{Rumen $\mathrm{pH}$}

We observed no effect of treatment on rumen $\mathrm{pH}$ mean, minimum, maximum, range, or time spent below $\mathrm{pH} 5.8$ or 5.6 (Table 2). Rumen $\mathrm{pH}$ is dependent on the rate of VFA synthesis and absorption, secretion of salivary buffer, and the endogenous buffering capacity of feeds/digesta (Allen, 1997). We did detect a treatment by time interaction for rumen $\mathrm{pH}$ in the current experiment $(P=0.02$; Figure 3$)$. Rumen $\mathrm{pH}$ was higher in $\mathrm{H} / \mathrm{L}$ than in $\mathrm{L} / \mathrm{H}$ before the evening feeding of the $\mathrm{LF}$ diet (1830 to $2030 \mathrm{~h}$ ) and was lower in $\mathrm{H} / \mathrm{L}$ than in $\mathrm{CON}$ and $\mathrm{L} / \mathrm{H}$ during the overnight period (0230 through $0430 \mathrm{~h}$ ). The increased $\mathrm{pH}$ before the evening feeding is in agreement with the reduction in feed intake that reduced entry of fermentable substrate into the rumen. The large amount of the LF diet that was consumed after feeding is expected to have reduced $\mathrm{pH}$ by increasing VFA synthesis, although a significant lag occurred between the evening feeding at $2200 \mathrm{~h}$ and the decrease in rumen $\mathrm{pH}$ at 0230 and $0430 \mathrm{~h}$.

We detected a main effect of time $(P<0.001)$ on rumen $\mathrm{pH}$ in the current experiment, and all treatments followed a similar daily pattern that progressively decreased after morning feeding and increased during the overnight period, similar to that reported by others (French and Kennelly, 1990; Beauchemin, 1991; Kononoff and Heinrichs, 2003). Although not measured in the current experiment, there is a daily rhythm of rumination, with less rumination during the light phase of the day and increased rumination during the over- 
YING ET AL.

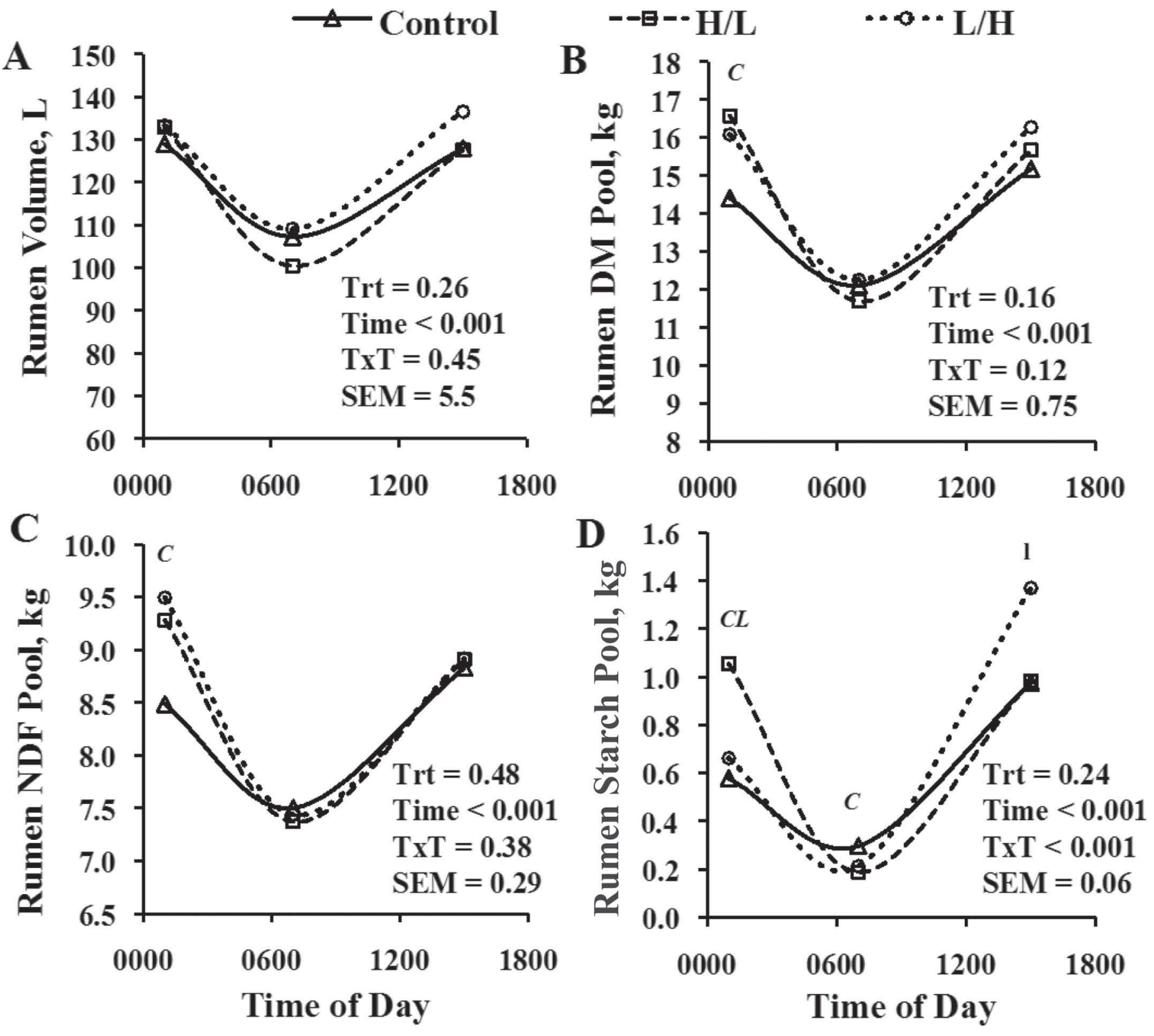

Figure 4. The effect of a single TMR or feeding 2 rations that differ in their fiber and starch concentration at different times of the day on (A) rumen volume and (B) DM, (C) NDF, and (D) starch pool sizes observed by rumen evacuation. Control cows were fed a TMR once per day at $0900 \mathrm{~h}, \mathrm{H} / \mathrm{L}$ were fed a high-fiber diet at $70 \%$ of daily offering at $0900 \mathrm{~h}$ and a low-fiber diet at $30 \%$ of daily offering at $2200 \mathrm{~h}$, and L/H were fed a low-fiber diet at $30 \%$ of daily offering at $0900 \mathrm{~h}$ and a high-fiber diet at $70 \%$ of daily offering at $1300 \mathrm{~h}$. Significance of treatment (Trt), time, and their interaction $(\mathrm{T} \times \mathrm{T})$ and SEM are shown. Preplanned contrasts at each time point are shown $($ control vs. H/L: C $=P$ $<0.01, C=P<0.05, \mathrm{c}=P<0.1 ; \mathrm{H} / \mathrm{L}$ vs. $\mathrm{L} / \mathrm{H}: \mathrm{L}=P<0.01, L=P<0.05, \mathrm{l}=P<0.1)$. Dark phase was approximately 0000 to 0500 h.

night period (Schirmann et al., 2012). The daily patterns of feed intake and rumination are nearly inverse of each other, which may simply be because little time is available for rumination during the day when cows are actively eating or, alternatively, may be a function of the higher fiber concentration of digesta during the overnight period.

\section{Rumen Digesta Nutrient Composition}

Rumen digesta composition was determined in grab samples representing every $3 \mathrm{~h}$ over the day. There was no treatment by time interaction for rumen $\mathrm{OM}$ and total FA concentration, although overall $\mathrm{OM}$ was 0.4 units higher in $\mathrm{H} / \mathrm{L}$ than in $\mathrm{CON}$ and $\mathrm{L} / \mathrm{H}(P=0.01)$. 
There was also an effect of time for both $\mathrm{OM}$ and FA concentrations $(P<0.001$; Supplemental Figure S1; http://dx.doi.org/10.3168/jds.2014-8873). We found a treatment by time interaction for starch and NDF concentrations. At $0100 \mathrm{~h}$, rumen NDF was almost $8 \%$ lower and starch was 25 and $60 \%$ higher in $\mathrm{H} / \mathrm{L}$ compared with $\mathrm{CON}$ and $\mathrm{L} / \mathrm{H}$, respectively, due to the high starch intake after feeding the LF diet in the evening. Similarly, after feeding the LF diet at $0900 \mathrm{~h}$, rumen NDF was $6.8 \%$ lower and starch concentration was $30 \%$ higher in $\mathrm{L} / \mathrm{H}$ compared with $\mathrm{H} / \mathrm{L}(P<0.05)$ due to the rapid intake of the LF diet after feeding in the morning.

\section{Rumen Pool Size}

Rumen nutrient pool size represents the amount of nutrients potentially available for microbial digestion and was observed through rumen evacuation at 3 time points selected to represent the smallest pool before morning feeding $(0700 \mathrm{~h})$ and near the expected peak pools after morning and evening feedings (1500 and $0100 \mathrm{~h}$ ). There was a treatment by time interaction for starch pool size and an effect of time on rumen DM, $\mathrm{OM}$, and NDF pool size and rumen volume (Figure 4; Supplemental Figure S2; http://dx.doi.org/10.3168/ jds.2014-8873). As expected, rumen volume and pool sizes were lowest before morning feeding $(0700 \mathrm{~h})$. Rumen DM and NDF pool size were increased at $0100 \mathrm{~h}$ by $\mathrm{H} / \mathrm{L}$ compared with $\mathrm{CON}$, but were not different between $\mathrm{H} / \mathrm{L}$ and $\mathrm{L} / \mathrm{H}$. Rumen starch pool size was $0.4 \mathrm{~kg}$ larger for $\mathrm{H} / \mathrm{L}$ at $0100 \mathrm{~h}$ compared with $\mathrm{CON}$ and $\mathrm{L} / \mathrm{H}$, but was $<0.1 \mathrm{~kg}$ smaller than $\mathrm{CON}$ at 0700 h. The increased DM and NDF pool size at night is presumably due to the large amount of feed consumed after the evening feeding of the $\mathrm{LF}$ diet in the $\mathrm{H} / \mathrm{L}$ treatment and due to the high NDF diet consumed during the afternoon and evening in the $\mathrm{L} / \mathrm{H}$ diet. Forage NDF has a longer rumen retention time, sustaining the increase in rumen pool size over time. Rumen pool sizes are normally averaged over the day, but the changes over the day highlight the effect of the daily rhythm of feed intake on the amount of nutrients available for microbial fermentation.

\section{Ruminal Fermentation Products}

Concentrations of VFA were determined in strained rumen fluid collected to represent every $3 \mathrm{~h}$ over the day. Surprisingly, we found no treatment by time interactions for total VFA concentration or concentration of individual VFA, but there was an effect of time,

Table 3. The effect of feeding a single TMR or feeding 2 rations that differ in their fiber and starch concentration at different times of the day on rumen digesta composition, VFA concentrations and profile, and ammonia concentration

\begin{tabular}{|c|c|c|c|c|c|c|c|c|c|}
\hline \multirow[b]{2}{*}{ Item } & \multicolumn{3}{|c|}{ Treatment $^{1}$} & \multirow[b]{2}{*}{ SEM } & \multicolumn{5}{|c|}{$P$-value ${ }^{2}$} \\
\hline & $\mathrm{CON}$ & $\mathrm{H} / \mathrm{L}$ & $\mathrm{L} / \mathrm{H}$ & & Trt & Time & $\begin{array}{l}\text { Trt } \times \\
\text { Time }\end{array}$ & $\begin{array}{c}\mathrm{H} / \mathrm{L} \\
\text { vs. } \mathrm{CON}\end{array}$ & $\begin{array}{c}\mathrm{H} / \mathrm{L} \\
\text { vs. } \mathrm{L} / \mathrm{H}\end{array}$ \\
\hline \multicolumn{10}{|c|}{ Rumen digesta, $\%$ of DM } \\
\hline $\mathrm{OM}$ & 93.6 & 94.0 & 93.6 & 0.38 & 0.01 & $<0.001$ & 0.99 & 0.01 & 0.01 \\
\hline Starch & 5.5 & 5.7 & 6.1 & 0.51 & 0.23 & $<0.001$ & 0.06 & 0.70 & 0.21 \\
\hline NDF & 62.5 & 61.3 & 61.4 & 0.44 & 0.03 & $<0.001$ & 0.01 & 0.02 & 0.81 \\
\hline FA & 3.82 & 3.93 & 3.92 & 0.09 & 0.38 & $<0.01$ & 0.90 & 0.20 & 0.84 \\
\hline \multicolumn{10}{|l|}{$\mathrm{VFA}, \mathrm{m} M$} \\
\hline Acetate & 68.9 & 68.6 & 70.5 & 1.93 & 0.17 & $<0.001$ & 0.17 & 0.84 & 0.09 \\
\hline Propionate & 26.0 & 26.3 & 25.7 & 1.34 & 0.59 & $<0.001$ & 0.16 & 0.66 & 0.31 \\
\hline Butyrate & 14.0 & 13.6 & 13.6 & 0.46 & 0.55 & $<0.001$ & 0.27 & 0.34 & 0.98 \\
\hline Valerate & 1.98 & 1.97 & 2.05 & 0.089 & 0.18 & $<0.001$ & 0.14 & 0.78 & 0.09 \\
\hline Branched $^{3}$ & 2.69 & 2.70 & 2.84 & 0.184 & 0.06 & $<0.001$ & 0.39 & 0.86 & 0.05 \\
\hline Total VFA & 113.5 & 113.1 & 114.5 & 2.62 & 0.74 & $<0.001$ & 0.15 & 0.86 & 0.46 \\
\hline \multicolumn{10}{|l|}{ VFA, mol \% } \\
\hline Acetate (A) & 60.9 & 60.8 & 61.5 & 0.90 & 0.01 & $<0.001$ & 0.60 & 0.90 & 0.01 \\
\hline Propionate $(\mathrm{P})$ & 22.8 & 23.0 & 22.4 & 1.03 & 0.08 & $<0.001$ & 0.24 & 0.32 & 0.03 \\
\hline Butyrate & 12.3 & 12.1 & 11.9 & 0.38 & 0.05 & $<0.001$ & 0.08 & 0.13 & 0.33 \\
\hline Valerate & 1.74 & 1.74 & 1.79 & 0.045 & 0.21 & $<0.001$ & 0.10 & 0.85 & 0.11 \\
\hline Branched & 2.35 & 2.36 & 2.46 & 0.155 & 0.05 & $<0.001$ & 0.11 & 0.74 & 0.05 \\
\hline $\mathrm{A}: \mathrm{P}$ ratio & 2.7 & 2.7 & 2.8 & 0.15 & 0.10 & $<0.001$ & 0.32 & 0.84 & 0.05 \\
\hline Ammonia, mg/dL & 7.8 & 8.5 & 8.3 & 0.63 & 0.24 & $<0.001$ & $<0.01$ & 0.10 & 0.65 \\
\hline
\end{tabular}

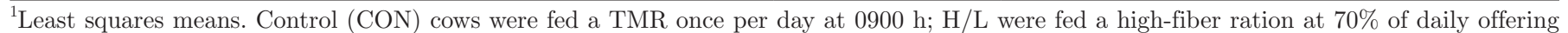
at $0900 \mathrm{~h}$ and a low-fiber ration at $30 \%$ of daily offering at $2200 \mathrm{~h}$; and $\mathrm{L} / \mathrm{H}$ were fed a low-fiber ration at $30 \%$ of daily offering at $0900 \mathrm{~h}$ and a high-fiber diet at $70 \%$ of daily offering at $1300 \mathrm{~h}$.

${ }^{2}$ Significance of preplanned contrasts (H/L vs. CON and H/L vs. L/H) and the main effect of treatment (Trt), time (time), and the interaction of treatment and time (Trt $\times$ Time).

${ }^{3}$ Isobutyrate plus isovalerate. 
with all VFA peaking near $1800 \mathrm{~h}$ (Table 3; Figure $5)$. There also was no overall effect of treatment other than a tendency for higher valerate (1.97 vs. $2.05 \mathrm{mM})$ and branched-chain VFA (2.84 vs. $2.7 \mathrm{mM}$ ) in $\mathrm{L} / \mathrm{H}$ compared with $\mathrm{H} / \mathrm{L}$ (Table 3). Additional differences were observed at each time point by the preplanned contrasts. Briefly, H/L increased propionate concentration $7.7 \%$ at $0000 \mathrm{~h}$ and tended to increase acetate and propionate approximately $9 \%$ at $0300 \mathrm{~h}$ compared with CON. This response is consistent with the increased fermentability and rapid intake of the LF diet consumed at the evening feeding and the increased rumen starch concentration and pool size during this period. In contrast, $\mathrm{H} / \mathrm{L}$ decreased total VFA concentration $11 \%$ and tended to decrease acetate and propionate concentration 9 and 14\%, respectively, at $0900 \mathrm{~h}$, demonstrating the lower fermentability of the HF diet fed at the morning feeding (Figure 6; Supplemental Figure S3; http://dx.doi.org/10.3168/jds.2014-8873).

We detected no treatment by time interaction for the molar percentages of acetate and propionate or the acetate-to-propionate ratio, but there was a main effect of treatment for acetate molar percentage and a tendency for a main effect of treatment for propionate (molar percentage as acetate was 1\% higher and propionate was $2.7 \%$ lower for $\mathrm{H} / \mathrm{L}$ compared with $\mathrm{L} / \mathrm{H}$; Table 3). As expected, there was an effect of time on the molar percentage of acetate and propionate and the acetate-to-propionate ratio, with high acetate from 0600 through $1500 \mathrm{~h}$ and high propionate from 1500 through $0300 \mathrm{~h}$ in all treatments (Supplemental Figure S4; http://dx.doi.org/10.3168/jds.2014-8873). There was a treatment by time interaction for the molar percentage of butyrate and a tendency for valerate and branched-chain VFA. Specifically, butyrate molar percentage was higher in $\mathrm{H} / \mathrm{L}$ compared with $\mathrm{L} / \mathrm{H}$ at $1200 \mathrm{~h}$, and it was lower in $\mathrm{H} / \mathrm{L}$ than in $\mathrm{CON}$ at 1500 h. Branched-chain VFA molar percentage was higher in $\mathrm{L} / \mathrm{H}$ than in $\mathrm{H} / \mathrm{L}$ at 0300,0600 , and $1500 \mathrm{~h}$. The daily changes in VFA concentration and profile demonstrate that a daily rhythm of fermentation occurred in all treatments, similar to that previously reported (Sutton et al., 1988; French and Kennelly, 1990; Gustafsson and Palmquist, 1993). Furthermore, the large amount of intake after feeding the LF diet in the $\mathrm{H} / \mathrm{L}$ treatment $(2030$ to $0030 \mathrm{~h})$ resulted in more starch fermentation during this period. It is notable that the treatments did not result in drastic changes in the daily pattern of rumen VFA, which may demonstrate the stability of rumen fermentation or the importance of the daily pattern of intake on VFA. Additionally, VFA synthesis is affected by substrate availability and enzymatic activity. Although not observed in the current experiment,
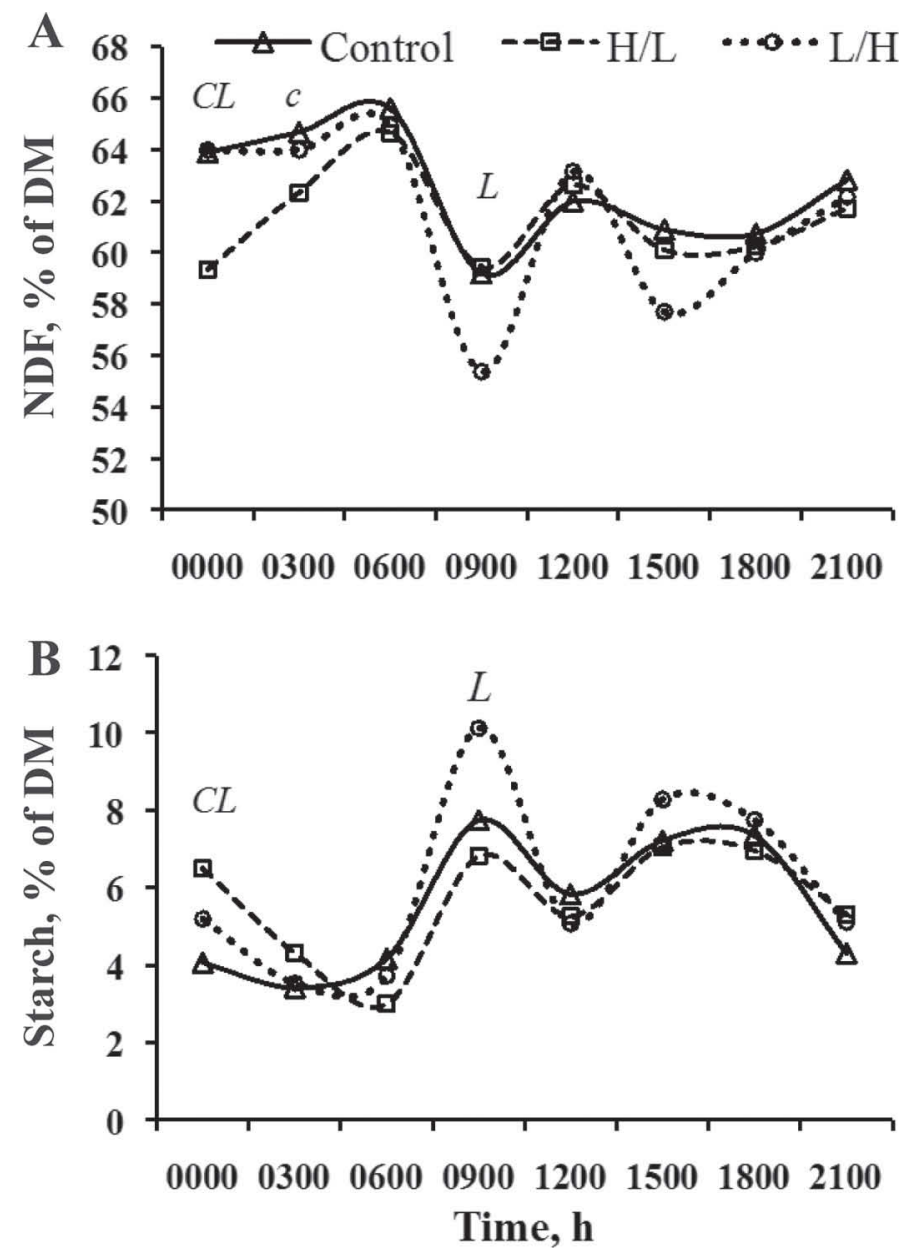

Figure 5. The effect of a single TMR or feeding 2 rations that differ in their fiber and starch concentration at different times of the day on rumen digesta NDF (A) and starch (B) concentration. Control cows were fed a TMR once per day at $0900 \mathrm{~h}, \mathrm{H} / \mathrm{L}$ were fed a high-fiber diet at $70 \%$ of daily offering at $0900 \mathrm{~h}$ and a low-fiber diet at $30 \%$ of daily offering at $2200 \mathrm{~h}$, and $\mathrm{L} / \mathrm{H}$ were fed a low-fiber diet at $30 \%$ of daily offering at $0900 \mathrm{~h}$ and a high-fiber diet at $70 \%$ of daily offering at $1300 \mathrm{~h}$. Significance of treatment, time, and their interaction and SEM reported in Table 3. Preplanned contrasts at each time point are shown (control vs. H/L: $C=P<0.05$ and $\mathrm{c}=P<0.1 ; \mathrm{H} / \mathrm{L}$ vs. $\mathrm{L} / \mathrm{H}$ : $L=P<0.05$ and $\mathrm{l}=P<0.1$ ). Dark phase was approximately 0000 to $0500 \mathrm{~h}$.

Fickett and Allen (2002) reported decreased capacity for starch digestion before feeding. In general, a daily pattern of total microbial cells, abundance of specific microbial populations, and enzymatic capacity of the microbial community are expected, but this daily pattern may not have been drastically changed by treatment in the current experiment.

We found a treatment by time interaction for rumen ammonia concentration $(P<0.01)$. Rumen ammonia was 30 and $75 \%$ higher in $\mathrm{H} / \mathrm{L}$ than in $\mathrm{CON}$ and $\mathrm{L} / \mathrm{H}$, respectively, at $1200 \mathrm{~h}$. This may be due to decreased $\mathrm{N}$ utilization after consuming a large amount of the 
HF diet at the morning feeding and an apparent high utilization of available $\mathrm{N}$ when feeding the LF diet in the morning. Interestingly, rumen ammonia increased after feeding the $\mathrm{HF}$ diet in the $\mathrm{L} / \mathrm{H}$ treatment, but was not different from $\mathrm{H} / \mathrm{L}$ at this time. This may be due to the lower intake of the $\mathrm{HF}$ diet in the $\mathrm{L} / \mathrm{H}$ treatment or to a higher concentration of rumen starch following consumption of the LF diet. Rumen ammonia was also $35 \%$ higher in $\mathrm{H} / \mathrm{L}$ than in $\mathrm{CON}$ at $0000 \mathrm{~h}$, which represents excess $\mathrm{N}$ after the very active feeding period following evening delivery of the LF diet. The large change in rumen ammonia over the day and the modification by feeding multiple rations within a day highlights the potential to improve nitrogen utilization by modification of protein fractions within a day. In the current experiment, the protein concentrate feeds (canola meal, cracked roasted soybeans, and nonprotein $\mathrm{N}$ supplement) were identical between the diets and $\mathrm{CP}$ was within 0.3 percentage units in an attempt to not confound diet fermentability with protein concentration or fractions. Feeding multiple diets within a day may benefit from a complementary protein profile based on the diet composition and rate of intake of the diet but requires further investigation.

$\rightarrow$ Control $-\because-\cdot \mathrm{H} / \mathrm{L} \cdots \cdots \mathrm{L} / \mathrm{H}$

A
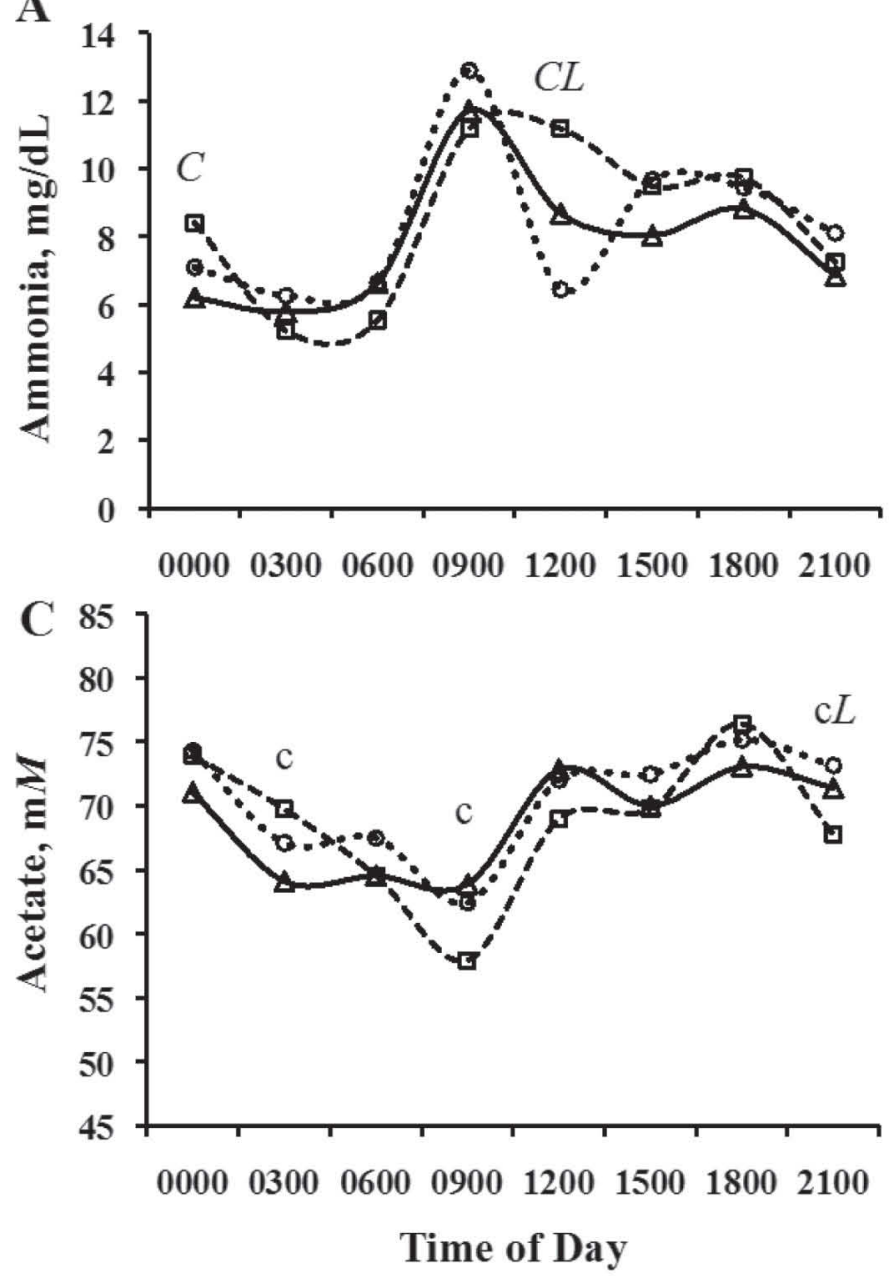

B
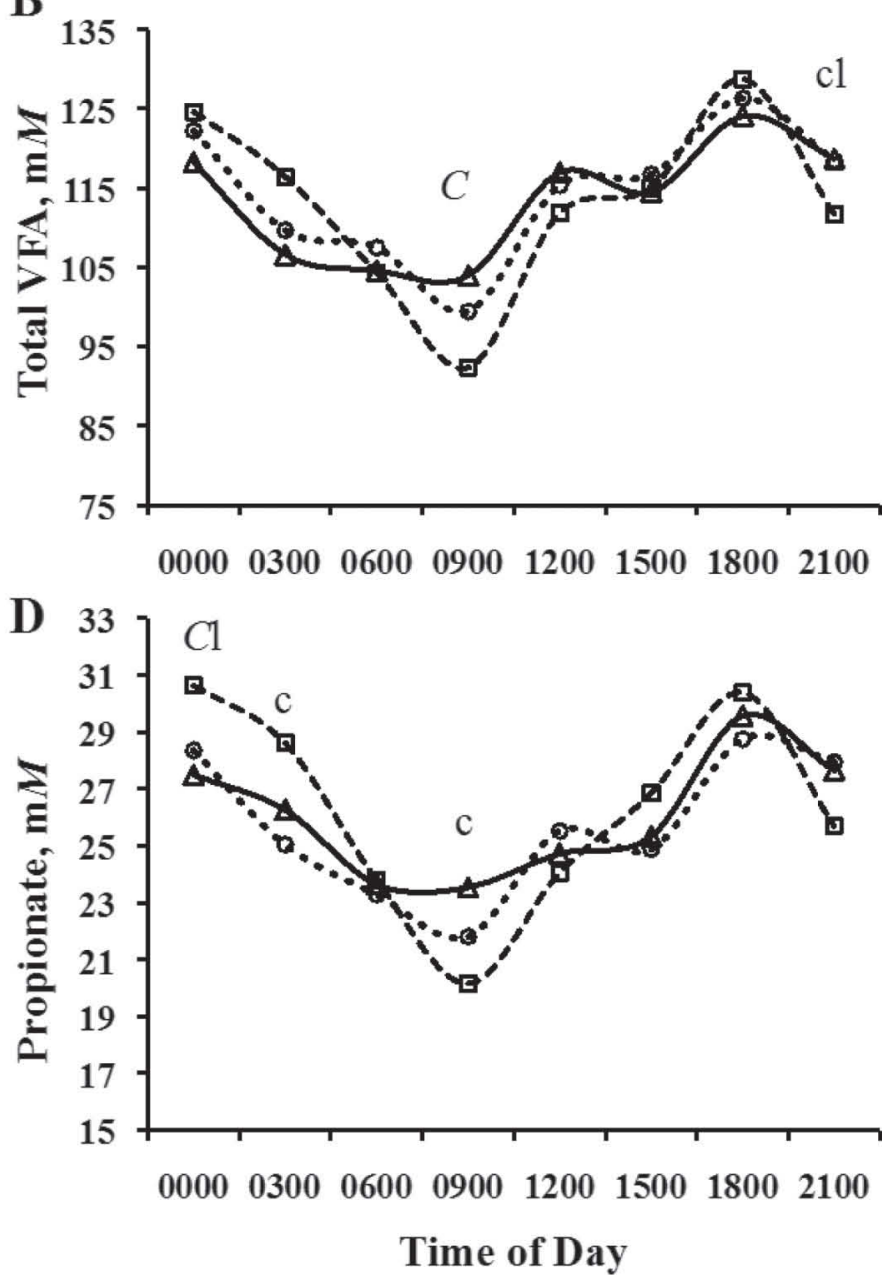

Figure 6. The effect of a single TMR or feeding 2 rations that differ in their fiber and starch concentration at different times of the day on rumen fluid (A) ammonia, (B) total VFA, (C) acetate, and (D) propionate concentrations. Control cows were fed a TMR once per day at 0900 $\mathrm{h}, \mathrm{H} / \mathrm{L}$ were fed a high-fiber diet at $70 \%$ of daily offering at $0900 \mathrm{~h}$ and a low-fiber diet at $30 \%$ of daily offering at $2200 \mathrm{~h}$, and $\mathrm{L} / \mathrm{H}$ were fed a low-fiber diet at $30 \%$ of daily offering at $0900 \mathrm{~h}$ and a high-fiber diet at $70 \%$ of daily offering at $1300 \mathrm{~h}$. Significance of treatment, time, and their interaction and SEM reported in Table 3. Preplanned contrasts at each time point are shown (control vs. $\mathrm{H} / \mathrm{L}: C=P<0.05$ and $\mathrm{c}=P$ $<0.1 ; \mathrm{H} / \mathrm{L}$ vs. $\mathrm{L} / \mathrm{H}: L=P<0.05$ and $\mathrm{l}=P<0.1)$. Dark phase was approximately 0000 to $0500 \mathrm{~h}$. 
Table 4. The effect of feeding a single TMR or feeding 2 rations that differ in their fiber and starch concentration at different times of the day on rumen digesta FA profile

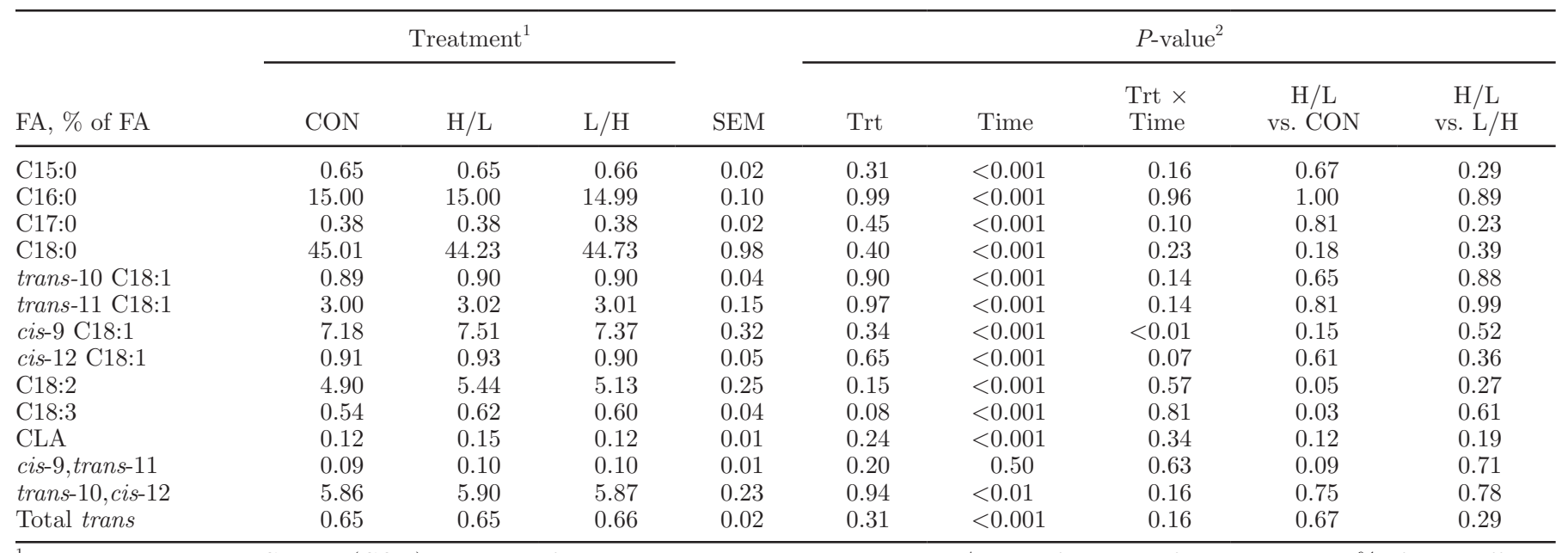

${ }^{1}$ Least squares means. Control $(\mathrm{CON})$ cows were fed a TMR once per day at $0900 \mathrm{~h} ; \mathrm{H} / \mathrm{L}$ were fed a high-fiber ration at $70 \%$ of daily offering at $0900 \mathrm{~h}$ and a low-fiber ration at $30 \%$ of daily offering at $2200 \mathrm{~h}$; and $\mathrm{L} / \mathrm{H}$ were fed a low-fiber ration at $30 \%$ of daily offering at $0900 \mathrm{~h}$ and a high-fiber diet at $70 \%$ of daily offering at $1300 \mathrm{~h}$.

${ }^{2}$ Significance of preplanned contrasts $(\mathrm{H} / \mathrm{L}$ vs. CON and $\mathrm{H} / \mathrm{L}$ vs. $\mathrm{L} / \mathrm{H})$ and the main effect of treatment (Trt), time (time), and the interaction of treatment and time $($ Trt $\times$ Time).

\section{Rumen FA Profile}

Rumen digesta long-chain FA profile was determined in grab samples every $3 \mathrm{~h}$ over the day to provide insight into substrate for biohydrogenation, rate and pathways of biohydrogenation, and changes in the microbial community (Table 4). Loor et al. (2004) reported a daily rhythm of rumen FA profile including the trans intermediates of biohydrogenation. The LF diet was slightly higher in cis-9 C18:1 and C18:2 (Table 1); concentrate feeds are a major source of these FA, whereas forages are higher in $\mathrm{C} 18: 3$. We detected a treatment by time interaction for cis-9 C18:1 as a percentage of total rumen FA, and cis-9 C18:1 was $>32 \%$ higher in $\mathrm{H} / \mathrm{L}$ than in CON from 0000 through $0300 \mathrm{~h}$ due to the large amount of the LF diet consumed after the evening feeding (Figure 7). Similarly, cis-9 C18:1 was 22\% higher in $\mathrm{L} / \mathrm{H}$ than in $\mathrm{H} / \mathrm{L}$ at $0900 \mathrm{~h}$, which followed morning feeding of the LF diet. Dietary unsaturated FA are biohydrogenated to form several intermediates (reviewed by Shingfield and Wallace, 2014). Trans-11 C18:1 is an intermediate of the normal biohydrogenation pathway that predominates with high-fiber diets, and trans-10 C18:1 and cis-12 C18:1 are intermediates of the alternate biohydrogenation pathway that occurs with higher starch diets and lower rumen $\mathrm{pH}$. There was a treatment by time interaction for cis-12 C18:1 ( $P$ $=0.07$ ) and tendencies for a treatment by time interaction for trans-10 C18:1 and trans-11 C18:1 $(P=0.14)$. Generally, trans-10 C18:1 and cis-12 C18:1 reached a nadir between 0600 and $0900 \mathrm{~h}$, whereas trans-11 C18:1 peaked between 0900 and $1500 \mathrm{~h}$ (Figure 7). Trans-10 C18:1 was nearly $8 \%$ lower in $\mathrm{H} / \mathrm{L}$ than in $\mathrm{L} / \mathrm{H}$ and tended to be lower than in CON at $2100 \mathrm{~h}$, immediately before the evening feeding of the LF diet. In contrast, trans-10 $\mathrm{C} 18: 1$ was over $13 \%$ higher in $\mathrm{H} / \mathrm{L}$ than in CON and L/H at 0300 h. Cis-12 C18:1 was over $20 \%$ higher in $\mathrm{H} / \mathrm{L}$ than in $\mathrm{CON}$ at 0000 and $0300 \mathrm{~h}$, and was over $25 \%$ higher than in $\mathrm{L} / \mathrm{H}$ at $0300 \mathrm{~h}$. Last, C15:0 and C17:0 are odd-chain FA originating from microbial synthesis and C17:0 is correlated with total microbial flow and higher fiber diets (Vlaeminck et al., 2006). No differences were observed in milk trans FA, although daily milk fat yield was lower in $\mathrm{H} / \mathrm{L}$ compared with $\mathrm{L} / \mathrm{H}$, and milk fat yield at the morning milking was lower in H/L than in CON (Rottman et al., 2015). We detected a tendency for a treatment by time interaction for $\mathrm{C} 17: 0(P=0.10)$, with a $>4 \%$ increase in $\mathrm{C} 17: 0$ in $\mathrm{H} / \mathrm{L}$ compared with $\mathrm{L} / \mathrm{H}$ at $2100 \mathrm{~h}$, but approximately a $3 \%$ decrease in $\mathrm{C} 17: 0$ in $\mathrm{H} / \mathrm{L}$ compared with $\mathrm{CON}$ at 0000 and $0300 \mathrm{~h}$. The decrease in C17:0 as a percent of total FA may be due to a dilution with feed FA but may also indicate reduced fibrolytic bacterial growth during this phase of the day for the $\mathrm{H} / \mathrm{L}$ treatment, when decreased acetate and increased intermediates of alternate biohydrogenation were also observed.

\section{Extrapolation to Other Situations}

Investigation of the daily pattern of feed intake and the effect of feeding different diets at different times of day highlights the direct effect of the timing of nutrient 

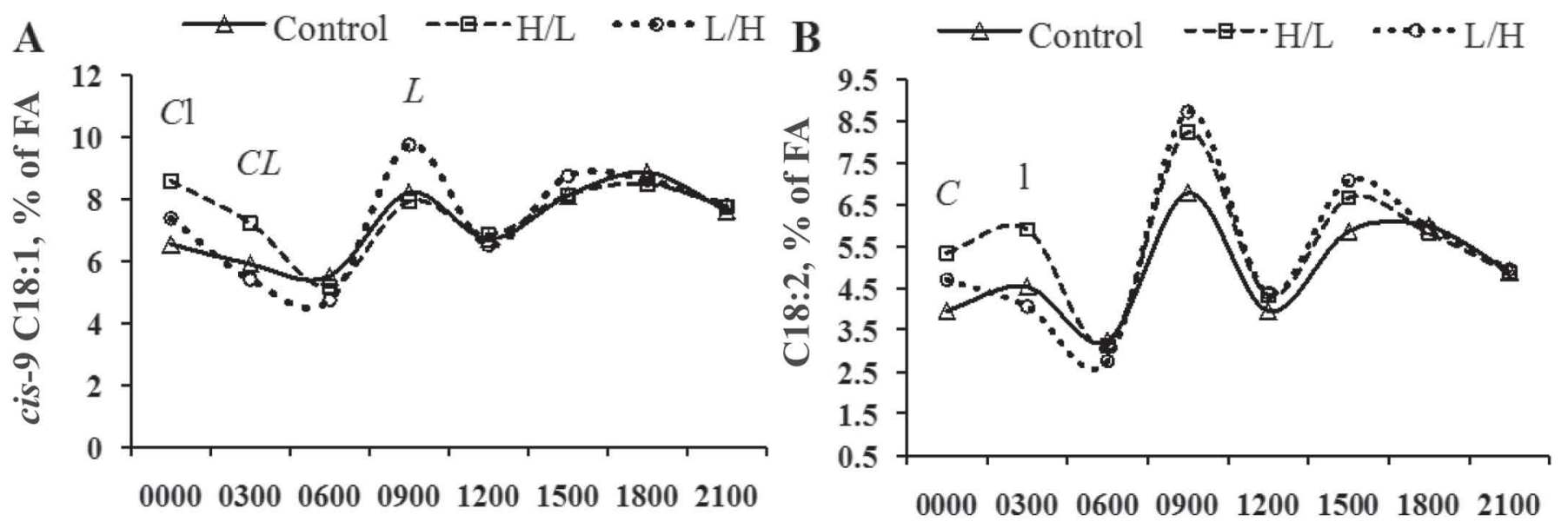

C

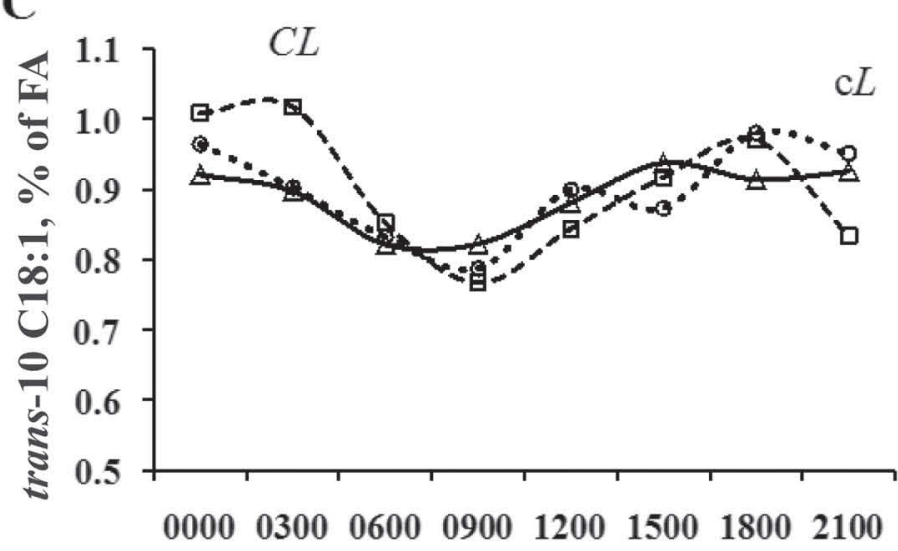

D
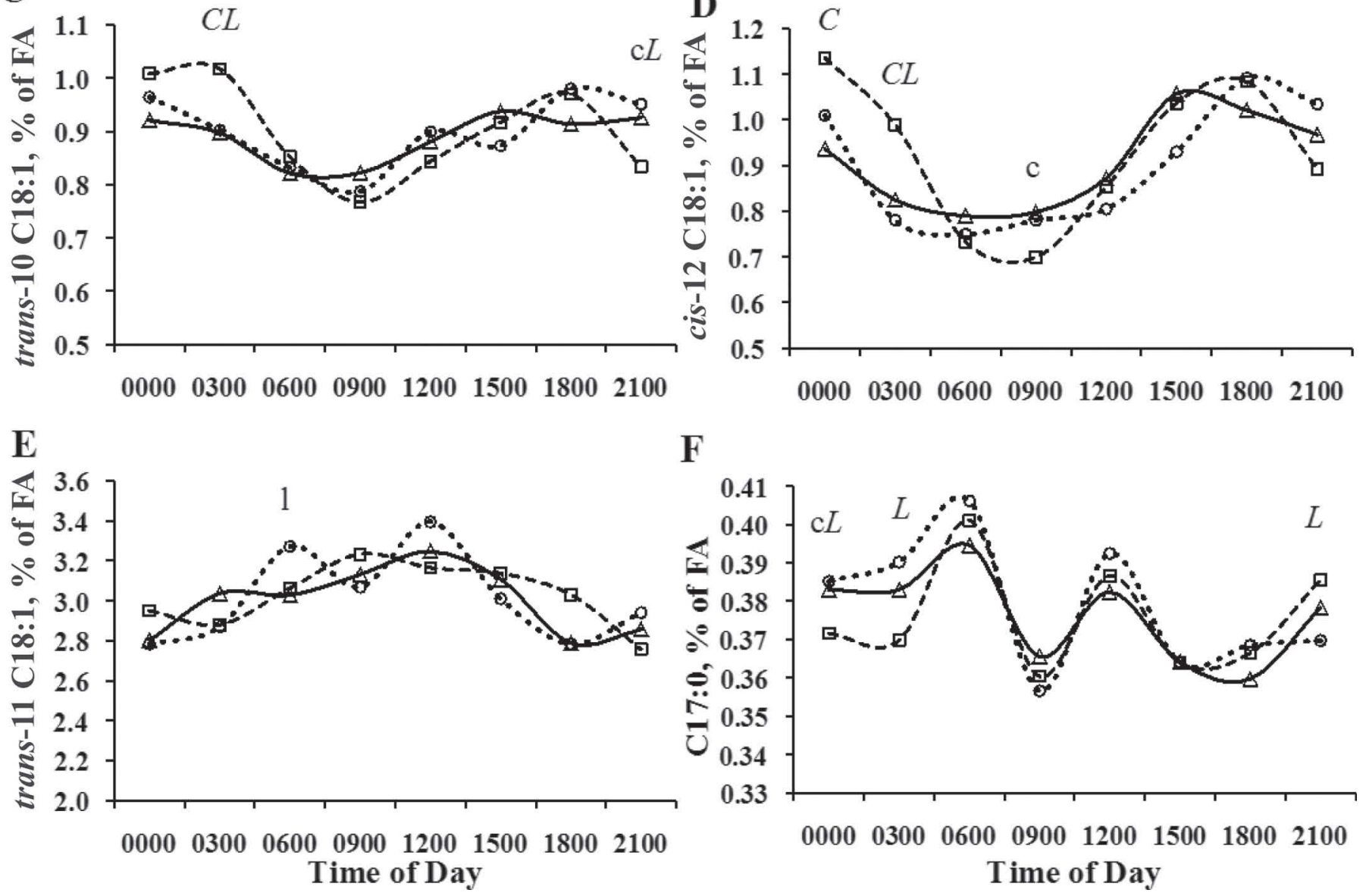

F

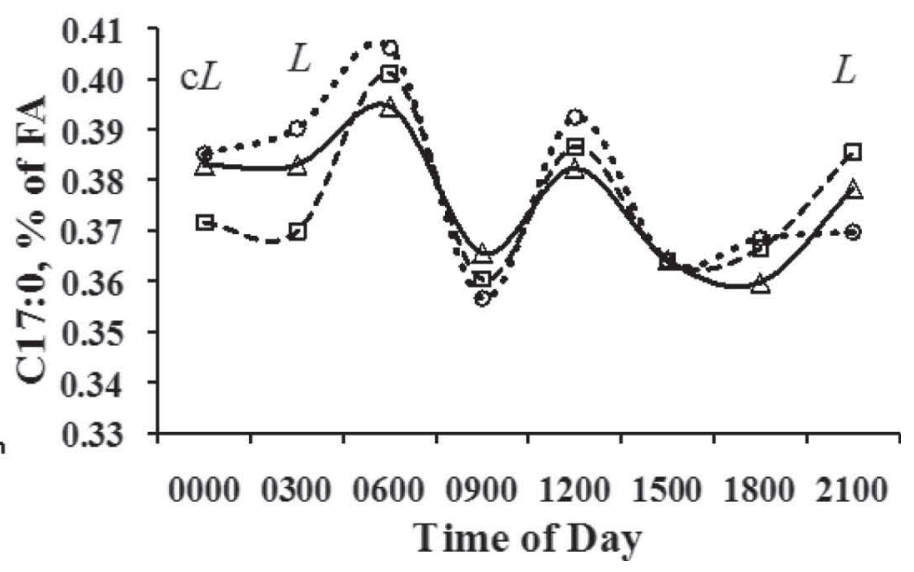

Figure 7. The effect of a single TMR or feeding 2 rations that differ in their fiber and starch concentration at different times of the day on rumen digesta FA profile including (A) cis-9, trans-11 C18:1, (B) C18:2, (C) trans-10 C18:1, (D) cis-12 C18:1, (E) trans-11 C18:1, and (F) C17:0 as a percentage of total FA. Control cows were fed a TMR once per day at $0900 \mathrm{~h}, \mathrm{H} / \mathrm{L}$ were fed a high-fiber diet at $70 \%$ of daily offering at $0900 \mathrm{~h}$ and a low-fiber diet at $30 \%$ of daily offering at $2200 \mathrm{~h}$, and $\mathrm{L} / \mathrm{H}$ were fed a low-fiber diet at $30 \%$ of daily offering at $0900 \mathrm{~h}$ and a highfiber diet at $70 \%$ of daily offering at $1300 \mathrm{~h}$. Significance of treatment, time, and their interaction and SEM reported in Table 4. Preplanned contrasts at each time point are shown (control vs. $\mathrm{H} / \mathrm{L}: C=P<0.05$ and c $=P<0.1 ; \mathrm{H} / \mathrm{L}$ vs. $\mathrm{L} / \mathrm{H}: L=P<0.05$ and $\mathrm{l}=P<0.1$ ). Dark phase was approximately 0000 to $0500 \mathrm{~h}$.

entry on rumen fermentation. Cows differ in the timing of nutrient intake over the day even when fed a single TMR because of differences in the timing and size of meals and feed sorting. Selective intake of concentrate has a larger potential effect during the early part of the day and a reduced effect as the day progresses because 
the remaining feed has a lower concentration of concentrate feeds due to prior sorting. The extent of sorting, effect of dietary factors on sorting, and the relationship between sorting and rumen parameters, such as $\mathrm{pH}$, has been extensively investigated (Leonardi et al., 2005; DeVries et al., 2007; Sova et al., 2013). Investigating the effect of sorting is difficult, with many experiments being confounded by daily fiber and starch intake. Arguably, the $\mathrm{L} / \mathrm{H}$ treatment in the current experiment is similar to some situations of sorting where a lower fiber diet is consumed during the first part of the day and a higher fiber diet is consumed later in the day. This treatment was expected to cause changes associated with acidosis but had little effect, possibly because of the high rumen $\mathrm{pH}$ and the low starch pool size before morning feeding. Surprisingly, the change in feeding behavior in the $\mathrm{H} / \mathrm{L}$ treatment caused changes associated with acidosis and highlights the important influence of the timing of feeding when offering multiple diets over the day.

\section{CONCLUSIONS}

There is a daily pattern of rumen digesta composition, pool sizes, and $\mathrm{pH}$ that is dependent on feeding behavior and the composition of the diet. Feeding multiple rations over the day has the potential to modify the daily pattern of nutrient entry into the rumen and rumen parameters, but changes in feeding behavior must be considered when feeding multiple rations over the day. Although feeding a high-fiber diet during the highintake period of the day and a low-fiber diet during the low-intake overnight period was expected to stabilize rumen fermentation, it failed to have the desired effect because of a modification of feeding behavior. In the current experiment, feeding a low-fiber diet at night drastically increased feed intake after feeding and resulted in increased rumen propionate and intermediates of the alternate biohydrogenation pathway. Modifying other dietary components within day, including protein fractions, may allow improved rumen fermentation or metabolic efficiency, but must be approached with an integrated understanding of cow behavior, rumen fermentation, and postabsorptive metabolism.

\section{ACKNOWLEDGMENTS}

Gratitude is expressed to Daniel Rico, Mutian Niu, Andrew Clarke, Grace Takacs, Ryan Fairbairn, Kaitlyn Proschold, and Megan Deeds (Penn State University, University Park, PA) for technical assistance and to all personnel at the Pennsylvania State University Dairy Cattle Research and Education Center for feeding and continuous care of animals. Research was supported by USDA Special Grant 2009-34281-20116 [to principal investigator Kevin Harvatine] and Penn State University (including a College of Agricultural Sciences Undergraduate Research Award to C.C.).

\section{REFERENCES}

Allen, M. S. 1997. Relationship between fermentation acid production in the rumen and the requirement for physically effective fiber. J. Dairy Sci. 80:1447-1462.

Beauchemin, K. A. 1991. Effects of dietary neutral detergent fiber concentration and alfalfa hay quality on chewing, rumen function, and milk production of dairy cows. J. Dairy Sci. 74:3140-3151.

Broderick, G. A., and J. H. Kang. 1980. Automated simultaneous determination of ammonia and total amino acids in ruminal fluid and in vitro media. J. Dairy Sci. 63:64-75.

Coppock, C. E., D. L. Bath, and B. J. Harris. 1981. From feeding to feeding systems. J. Dairy Sci. 64:1230-1249.

Dado, R. G., and M. S. Allen. 1994. Variation in and relationships among feeding, chewing, and drinking variables for lactating dairy cows. J. Dairy Sci. 77:132-144.

DeVries, T. J., K. A. Beauchemin, and M. A. von Keyserlingk. 2007. Dietary forage concentration affects the feed sorting behavior of lactating dairy cows. J. Dairy Sci. 90:5572-5579.

DeVries, T. J., M. A. von Keyserlingk, and K. A. Beauchemin. 2003. Short communication: Diurnal feeding pattern of lactating dairy cows. J. Dairy Sci. 86:4079-4082.

DeVries, T. J., M. A. G. von Keyserlingk, and K. A. Beauchemin. 2005. Frequency of feed delivery affects the behavior of lactating dairy cows. J. Dairy Sci. 88:3553-3562.

Fickett, F. M., and M. S. Allen. 2002. Ruminal fluid effects on in vitro digestion kinetics of corn starch. J. Dairy Sci. 85(Suppl. 1):181. (Abstr.)

French, N., and J. J. Kennelly. 1990. Effects of feeding frequency on ruminal parameters, plasma insulin, milk yield, and milk composition in Holstein cows. J. Dairy Sci. 73:1857-1863.

Gustafsson, A. H., and D. L. Palmquist. 1993. Diurnal variation of rumen ammonia, serum urea, and milk urea in dairy cows at high and low yields. J. Dairy Sci. 76:475-484.

Kononoff, P. J., and A. J. Heinrichs. 2003. The effect of reducing alfalfa haylage particle size on cows in early lactation. J. Dairy Sci. 86:1445-1457.

Krause, K. M., and G. R. Oetzel. 2006. Understanding and preventing subacute ruminal acidosis in dairy herds: A review. Anim. Feed Sci. Technol. 126:215-236.

Leonardi, C., F. Giannico, and L. E. Armentano. 2005. Effect of water addition on selective consumption (sorting) of dry diets by dairy cattle. J. Dairy Sci. 88:1043-1049.

Loor, J. J., K. Ueda, A. Ferlay, Y. Chilliard, and M. Doreau. 2004. Short communication: Diurnal profiles of conjugated linoleic acids and trans fatty acids in ruminal fluid from cows fed a high concentrate diet supplemented with fish oil, linseed oil, or sunflower oil. J. Dairy Sci. 87:2468-2471.

Oba, M., and M. S. Allen. 2000. Effects of brown midrib 3 mutation in corn silage on productivity of dairy cows fed two concentrations of dietary neutral detergent fiber: 1. Feeding behavior and nutrient utilization. J. Dairy Sci. 83:1333-1341.

Owens, F. N., D. S. Secrist, W. J. Hill, and D. R. Gill. 1998. Acidosis in cattle: A review. J. Anim. Sci. 76:275-286.

Rico, D. E., Y. Ying, and K. J. Harvatine. 2014. Effect of a highpalmitic acid fat supplement on milk production and apparent total-tract digestibility in high- and low-milk yield dairy cows. J. Dairy Sci. 97:3739-3751.

Rottman, L. W., Y. Ying, K. Zhou, P. A. Bartell, and K. H. Harvatine. 2015. The effects of feeding rations that differ in NDF and starch concentration within a day on production, feeding behavior, total- 
tract digestibility and plasma metabolites and hormones in dairy cows. J. Dairy Sci. 98:4673-4684. 10.3168/jds.2014-8859.

Schirmann, K., N. Chapinal, D. M. Weary, W. Heuwieser, and M. A. G. von Keyserlingk. 2012. Rumination and its relationship to feeding and lying behavior in Holstein dairy cows. J. Dairy Sci. 95:3212-3217.

Shingfield, K. J., and R. J. Wallace. 2014. Synthesis of conjugated linoleic acid in ruminants and humans. Pages 1-64 in Conjugated Linoleic Acids and Conjugated Vegetable Oils. B. Sels and A. Philippaerts, ed. Royal Society of Chemistry, London, UK.

Sova, A. D., S. J. LeBlanc, B. W. McBride, and T. J. DeVries. 2013. Associations between herd-level feeding management practices, feed sorting, and milk production in freestall dairy farms. J. Dairy Sci. 96:4759-4770.

Sutton, J. D., I. C. Hart, S. V. Morant, E. Schuller, and A. D. Simmonds. 1988. Feeding frequency for lactating cows: Diurnal pat- terns of hormones and metabolites in peripheral blood in relation to milk-fat concentration. Br. J. Nutr. 60:265-274.

Tolkamp, B. J., D. J. Allcroft, J. P. Barrio, T. A. Bley, J. A. Howie, T. B. Jacobsen, C. A. Morgan, D. P. Schweitzer, S. Wilkinson, M. P. Yeates, and I. Kyriazakis. 2011. The temporal structure of feeding behavior. Am. J. Physiol. Regul. Integr. Comp. Physiol. 301:R378-R393.

Vlaeminck, B., V. Fievez, S. Tamminga, R. J. Dewhurst, A. van Vuuren, D. De Brabander, and D. Demeyer. 2006. Milk odd- and branched-chain fatty acids in relation to the rumen fermentation pattern. J. Dairy Sci. 89:3954-3964.

Yang, C. M., and G. A. Varga. 1989. Effect of three concentrate feeding frequencies on rumen protozoa, rumen digesta kinetics, and milk yield in dairy cows. J. Dairy Sci. 72:950-957. 